\title{
ANALISIS PENGARUH FAKTOR PRODUKSI DAN TINGKAT PRODUKTIVITAS KELAPA SAWIT DI KABUPATEN SELUMA
}

\author{
Jalal Ikhwan'1dan Hesti Aryanti² \\ 1 Universitas Prof. Dr. Hazairin, SH \\ 2 Universitas Prof. Dr. Hazairin, SH \\ ikhwan1296@yahoo.com; 085268726625
}

\begin{abstract}
Abstrak
Penelitian ini bertujuan untuk mengetahui besarnya pengaruh faktor produksi yaitu: luas lahan, tenaga kerja, dan modal secara simultan maupun secara parsial terhadap tingkat produksi kelapa sawit di Kabupaten Seluma dan mengetahui bagaimana tingkat prduktivitas kelapa sawit di Kabupaten Seluma.Hasil output SPSS diperoleh persamaan regresi linier berganda Ln $Y=7,822+0,774 \operatorname{Ln} X_{1}+0,148 \operatorname{Ln} X_{2}+0,430 \operatorname{Ln} X_{3}+$ è (dimana $\mathrm{Y}=$ Jumlah Produksi, $\mathrm{X}_{1}=$ Luas Lahan, $\mathrm{X}_{2}=$ Tenaga Kerja, dan $\mathrm{X}_{3}=$ Modal). Nilai koefesien korelasi $(\mathrm{R})=0,835$ artinya hubungan antara indenpenden dan dependen sangat kuat dan bersifat positif sedangkan koefesien determinasinya $\left(\mathrm{R}^{2}\right)=0,697$ atau 69,7 persen jumlah produksi kelapa sawit di Kecamatan Seluma Selatan ditentukan oleh ketiga variabel indipenden sedangkan sisanya sebesar 30,3 persen dijelaskan oleh variabel lain diluar penelitian ini.Hasil uji-t dengan tingkat keyakinan (level of significant) sebesar $95 \%$ diperoleh t-tabel 1,6 dengan hasil uji-t masing-masing variabel adalah: variabel $X_{1}(4,901>1,960)$, variabel $X_{2}$ $(1,534<1,960)$, dan variabel $X_{3}(2,296>1,960)$, artinya berdasarkan uji-t terbukti hanya variabel luas lahan $\left(\mathrm{X}_{1}\right)$ dan faktor modal $\left(\mathrm{X}_{3}\right)$ yang berpengaruh secara signifikan terhadap variabel dependen (jumlah produksi kelapa sawit), sedangkan variabel tenaga kerja $\left(\mathrm{X}_{2}\right)$ tidak terbukti berpengaruh terhdap variabel dependen (jumlah produksi kelapa sawit). Uji-F diperoleh hasil $F_{\text {-hitung }}>F_{\text {-tabel }}$ yaitu 86,513 > 2,840, artinya secara simutlan ketiga variabel indipenden terbukti mempengarui jumlah produksi kelapa sawit di Kabupaten Seluma.
\end{abstract}

Kata Kunci: Jumlah produksi; luas lahan; tenaga kerja; modal

\section{PENDAHULUAN}

Penduduk Kabupaten Seluma merupakan masyarakat agraris dimana masyarakatnya mayoritas mempunyai perkebunan kelapa sawit telah berhasil mendorong laju pertumbuhan ekonomi Kabupaten Seluma dengan kontribusi sektor pertanian dan perkebunan pada tahun 2015 sebesar 53.82 persen. Keadaan ini tentunya tak lepas dari potensi, lokasi, modal, pengelolahan lahan, pembibitan, tenaga kerja perkebunan kelapa sawit ini sendiri. Faktor-faktor tersebut merupakan sesuatu yang mutlak dan harus terpenuhi oleh perkebunan kelapa sawit dalam usaha meningkatkan produksinya sesuai dengan keinginan masyarakat dan pemerintah Kabupaten Seluma.

Dalam laporannya Sugandi (2016), menyampaikan beberapa rekomendasi yang harus dilakukan Pemerintah Daerah Propinsi Bengkulu dalam menunjang dan membantu agar terciptanya sentra produksi pertanian dan perkebunan khususnya untuk perkebunan kelapa sawit di Propinsi Bengkulu, adalah sebagai berikut:

a. Pemerintah harus membantu dalam pembuatan lahan baru melalui pengerukan, pembuatan irigasi rawa (lahan gambut), supaya lahan tersebut dapat ditanami bibit kelapa sawit.

b. Pemerintah memberikan pupuk bersubsidi pada petani dengan pengawasan yang ketat sehingga petani bisa memperoleh penghasilan yang tinggi sesuai dengan kebutuhan dan bisa menggunakannya secara rutin serta teratur sehingga kebun kelapa sawit dapat berhasil dengan baik.

c. Pemerintah juga memberikan bantuan kepada petani berupa bantuan bibit kelapa sawit siap tanam untuk meringankan biaya petani dan supaya dapat mencapai hasil produksi yang maksimal.

Dalam rencana kerja pembangunan daerah (RKPD) Kabupaten Seluma tahun 2016, disebutkan bahwa permasalahan pembangunan pedesaan dari segi kondisi rumah tangga yang terjadi dewasa 
ini adalah : (1) banyaknya penduduk pedesaan yang kurang memiliki pengetahuan dan keterampilan dasar masyarakat dalam pengelolaan usaha pertanian, (2) banyaknya keluarga yang menggantungkan pada ciri pertanian subsisten, dan (3) banyaknya keluarga yang memiliki lahan marginal atau luas lahan yang makin menyempit. Pembangunan disektor pertanian khususnya perkebunan kelapa sawit merupakan kompnen penting dalam perencanaan pembangunan ekonomi daerah Kabupaten Seluma karena karakteristik wilayah yang agraris, ketersediaan tenaga kerja dan komposisi mata pencaharian masyarakatnya yang mayoritas adalah petani.

\section{TINJAUAN PUSTAKA}

\subsection{Teori Produksi}

Produksi adalah setiap aktivitas yang menciptakan kegunaan (utility) dari barang ekonomi untuk sekarang maupun dimasa yang akan datang (Letwich, 2004). Sedangkan Sudarman (2011) menjelaskan bahwa: produksi bukan saja meliputi perolehan dalam sifat dan bentuk suatu usaha saja, melainkan sebagai akibat dari adanya kebutuhan manusia yang jumlah dan jenisnya lebih banyak apabila dibandingkan dengan jumlah usaha atau jasa yang dihasilkan oleh berbagai jenis faktor pendaptan yang tersedia.

Assauri (2013) mengemukakan bahwa produksi adalah kegiatan mencitakan atau menambah kegunaan (utility) sesuatu barang atau menambah kegunaan (utility) sesuatu barang atau jasa dengan menggunakan sumber-sumber (tenaga kerja, bahan-bahan, dan modal) yang ada. Sedangkan Soeharno (2006) menjelaskan bahwa produksi adalah merubah bahan atau komponen (produksi) menjadi barang jadi. Definisi lain dikemukakan oleh Gusti (2014), mengemukakan bahwa produksi adalah sebagai hasil proses aktivitas ekonomi dengan manfaat sumber daya yang tersedia serta memiliki potensi sebagai faktor produksi dan Hermanto (2014) mengemukakan bahwa produksi adalah suatu proses untuk memenuhi kebutuhan untuk penyelengaran jasa-jasa lain yang dapat memenuhi kebutuhan manusia. Oleh karena itu produksi merupakan tindakan manusia untuk menciptakan atau menambah nilai guna barang sesuai dengan yang dikehendaki.

Hubungan antara input dan output menurut Nicholson (2013) dapat diformulasikan kedalam suatu fungsi produksi dengan bentuk:

$$
\mathrm{Q}=\mathrm{f}(\mathrm{K}, \mathrm{L}, \mathrm{M}) \ldots(1)
$$

Keterangan :

$\mathrm{Q}$ adalah menunjukan output suatu barang tertentu dalam satu periode

$\mathrm{K}$ adalah menunjukan pemakaian modal selama periode tertentu

$\mathrm{L}$ adalah menunjukan pemakaian tenaga kerja

$\mathrm{M}$ adalah menunjukan bahan mentah yang digunakan

Apabila hanya terdapat 2 kombinasi faktor produksi, yaitu tenaga kerja dan modal yang digunakan dalam proses produksi untuk menghasilkan output tertentu dalam proses produksi, maka fungsi produksi tersebut dapat ditulis menjadi

$$
Q=f(K, L) \ldots(2)
$$

\subsection{Faktor Produksi}

Dalam aktivitas produksinya produsen mengubah berbagai faktor produksi menjadi barang dan jasa. Berdasarkan hubungannya dengan tingkat produksi, faktor produksi dibedakan menjadi faktor tetap (fixed input) dan faktor produksi variabel. Menurut Mubyarto (2006) menyatakan bahwa produksi petani adalah hasil yang dalam bidang pertanian istilah yang dimaksud yaitu hasil pekerjaan beberapa faktor produksi secara sekaligus, dengan demikian faktor-faktor ekonomi yang berpengaruh terhadap produksi khususnya lahan, dan modal, 
tingkat kesuburan, dan faktor-faktor lain yang melekat dalam faktor lahan itu sendiri.

Menurut Adiningsih (2007) faktor produksi adalah barang dan jasa yang digunakan sebagai masukan pada proses produksi. Selain itu faktor produksi sering juga disebut dengan Pengorbanan produksi, karena faktor produksi tersebut dikorbankan untuk menghasilkan produksi (Soekarwati, 2006). Lalu menurut Raharja dan Manurung (2006) menjelaskan bahwa untuk memproduksi barang dan jasa perusahaan membutuhkan beberapa faktor produksi pokok, yaitu :

1. Tenaga kerja, dengan balas jasa atau upah gaji

2. Barang modal, dengan balas jasa berupa sewa

3. Uang, dengan balas jasa berupa bunga

\subsection{Luas Lahan}

Tanah sebagai salah satu faktor produksi adalah merupakan pabriknya hasil-hasil pertanian, yaitu tempat dimana produksi berjalan dan dimana hasil produksi keluar dalam pertanian. Faktor produksi mempunyai kedudukan paling penting. Hal ini terbukti dari besarnya balas jasa yang terima oleh tanah dibandingkan faktor-faktor produksi kerja dapat pula dibuktikan dengan tinggi rendahnya balas jasa atau sewa bagi hasil yang sesuai dengan permintaan dan penawaran tanah itu dalam masayarakat (Mubyarto, 2006).

Tanah adalah faktor produksi yang disediakan oleh alam (Sukirno, 2006), secara rinci Hermanto (2014) menjelaskan bahwa tanah merupakan faktor produksi yang memiliki sifat:

a. Relatif langka dibanding faktor produksi lainnya

b. Distribusi penguasaannya dimasyarakat tidak merata.

Tanah juga memiliki beberapa sifat antara lain :

a. Luasnya relatif tetap atau dianggap tetap

b. Tidak dapat dipindah-pindahkan

c. Dapat dipindah tangankan atau diperjual-belikan

\subsection{Tenaga Kerja}

Mubyarto (2006), menyatakan bahwa tenaga kerja dalam pertanian di Indonesia harus dibedakan dalam dua bentuk, yaitu tenaga kerja petani kecil-kecilan (usaha pertanian rakyat) dan tenaga kerja dalam perusahaan pertanian besar (perkebunan, kehutanan, dan perternakan). Perbedaan ini penting karena apa yang dikenal sebagai tenaga kerja dalam petani tidaklah sama pengertiannya secara ekonomis dengan pengertian tenaga kerja dalam perusahaan-perusahaan pertanian. Dalam petani sebagian besar tenaga kerja berasal dari keluarga petani itu sendiri yaitu terdiri dari ayah sebagai kepala keluarga, istri dan anak-anak petani itu sendiri. Tenaga kerja yang berasal dan keluarga petani ini merupakan sumbangan keluarga pada produksi pertanian secara keseluruhan dan tidak pernah dinilai dengan uang.

\subsection{Modal}

Modal dapat mempunyai berbagai arti, modal dapat merupakan sejumlah uang, barang cadangan yang merupakan bahan mentah, barang setengah jadi dan barang jadi. Modal berupa uang dapat dipinjamkan dan pemiliknya menerima imbalan yang disebut bunga (Djoyodipuro, 1994: 113). Modal dimaksud disini adalah modal kerja dalam usaha menambah output yang diinginkan yaitu modal yang berwujud kekayaan dalam bentuk uang untuk mrmbeli bahan baku dan untuk membayar upah tenaga kerja dalam proses produksi dan modal kerja itu sendiri adalah sejumlah dana yang dibutuhkan oleh perusahaan untuk membelanjai operasi perusahaan sehari-hari serta diharapkan dapat kembali dalam jangka waktu pendek.

\section{METODE}


Sifat penelitian ini adalah penelitian survey dan juga prosedur yang dilakukan mengumpulkan informasi guna memecahkan masalah dan menguji hipotesis. Penelitian survey menurut Husein (2007) digunakan untuk mengukur gejala-gejala yang data yang ada, bukan menguji hipotesis untuk memecahkan masalah. Survei dapat memberikan manfaat untuk tujuan-tujuan yang bersifat deskriptif, membandingkan kondisi-kondisi yang ada dengan kriteria yang telah ditentukan sebelumnya dan membantu pelaksanaan evaluasi. Survei dapat dilakukan dengan cara sensus maupun sampling terhadap hal-hal yang nyata dan tidak nyata.

\section{HASIL DAN PEMBAHASAN}

Untuk menganalisis bagaimana pengaruh luas lahan, tenaga kerja dan modal pada petani sawit di Kecamatan Seluma Barat Kabupaten Seluma, dalam pembahasan ini menggunakan fungsi CobbDouglass. Berdasarkan perhitungan yang dilakukan menggunakan program SPSS For Window 21, dapat dilihat pada Tabel 1. dibawah ini:

Tabel 1.Estimasi dari Fungsi Produksi Petani Sawit di Kabupaten Seluma

\begin{tabular}{lccc}
\hline Variable & Koefisien & t-test & Sig. \\
\hline LL (Luas Lahan) & 0,774 & 4,901 & 0,000 \\
TK (Tenaga Kerja) & 0,148 & 1,534 & 0,072 \\
M (Modal) & 0,430 & 2,926 & 0,004 \\
\hline Intersep7,822 & & & \\
R0,835 & & & \\
$\mathrm{R}^{2} 0,697$ & & & \\
f-test86,513 & & &
\end{tabular}

Berdasarkan dari tabel 1. Tersebut dapat ditulis dalam bentuk persamaan:

$$
\operatorname{Ln} Y=7,822+0,744 \operatorname{Ln} X_{1}+0,148 \operatorname{Ln} X_{2}+0,430 \operatorname{Ln} X_{3}+\grave{e ̀ . . .(3) ~}
$$

Dari persamaan diatas dapat diketahui bawa niali konstanta yang ada sebesar 7,822 yang artinya jika faktor-faktor produksi luas lahan, tenaga kerja dan modal sama dengan nol, maka produksi sawit akan tetap sebesar 7,822.

Koefisien luas lahan $\left(\mathrm{X}_{1}\right)$ mempunyai tanda positif artinya luas lahan berpengaruh positif terhadap produksi sawit. Hal ini berarti apabila luas lahan ditambah $1 \%$ maka jumlah produksi sawit akan meningkat sebesar 0,774 satuan, bermakna bahwa pertambahan sejumlah luas lahan tidak diimbangi secara proporsional oleh tambahan jumlah produksi yang diperoleh sehingga bisa dikatakan pemanfaatan luas lahan yang ada di Kecamatan Seluma Barat Kabupaten Seluma belum maksimal atau belum mencapai produktivitas yang maksimal dari pemanfaatan lahan itu sendiri. Sehubungan dengan kondisi ini petani kelapa sawit Kecamatan Seluma Barat untuk meningkatkan produktivitas penggunaan lahan diharapkan dapat meningkatkan produktivitas lahan dengan cara mengolah lahan yang ada secara produktif dan efisien seperti menggemburkan tanah secara matang dan selalu membersihkan rumput hama atau gulma yang ada disekitar lahan yang dapat mengurangi tingkat kesuburan tanah dengan cara perawatan tersebut sehingga zat humus tanah terjaga dan kesuburan tanah tersebut benar-benar untuk menunjang kesuburan tanaman sawit tersebut.

Koefisien untuk tenaga kerja $\left(\mathrm{X}_{2}\right)$ mempunyai tanda positif terhadap jumlah produksi sawit yang artinya apabila tenaga kerja ditambah $1 \%$ maka jumlah produksi sawit akan naik sebesar 0 , 148 satuan, hal ini berarti pertambahan penggunaan tenaga kerja di Kecamatan Seluma Barat akan menambah jumlah produksi. Maka dari itu diharapkan bagi petani di Kecamatan Seluma Barat Kabuapten Seluma untuk meningkatkan produktifitas tenaga kerja yang produktif saja mengolah lahan sampai panen tiba dan disarankan bagi petani untuk dapat mengawasi setiap saat tenaga kerja yang bekerja di kebun sawit sehingga tenaga kerja tersebut bekerja secara optimal dan terkontrol setiap saat. 
Koefisien untuk penggunaan pupuk $\left(\mathrm{X}_{3}\right)$ mempunyai tanda positif yang artinya modal mempunyai pengaruh terhdap produksi kebun sawit, hal ini berarti apabila modal ditambah $1 \%$ maka jumlah produksi akan meningkat sebesar 0,430 satuan, yang bermakna apabila pertambahan sejumlah modal tidak diimbangi secara proporsional oleh pertambahan jumlah produksi yang diperoleh sehingga bisa dikatakan penambahan modal yang ada di Kecamatan Seluma Barat Kabupaten Seluma belum mksimal atau belum mencapai produktivitas maksimal dari penggunaan modal itu sendiri. Maka dari itu diharapkan bagi petani untuk meningkatkan produktivitas penggunaan modal dengan mengatur penggunaan modal sesuai dengan luas lahan yang mereka garap.

Dari persamaan fungsi Cobb-Douglas diatas juga terlihat perbedaan nilai elastisitas masingmasing variabel luas lahan, tenaga kerja dan modal. Dari ketiga variabel diatas menunjukkan bahwa variabel yang paling berperan dalam proses produksi sawit di Kecamatan Seluma Barat Kabupaten Seluma adalah luas lahan $\left(\mathrm{X}_{1}\right)$. Oleh karena itu dengan semakin terbatasnya lahan yang dimiliki oleh petani untuk dapat memperluas lahannya sehingga diharapkan petani di Kecamatan Seluma Barat sangat perlu melakukan pengolahan lahan yang lebih produktif agar mereka dapat meningkatkan produksi sawit untuk masa yang akan datang.

Selain itu juga variabel modal sangat berperan penting dalam proses produksi, maka petani di kelurahan ini sangat perlu memperhatikan setiap penambahan modal untuk setiap hektar agar dapat mecapai produksi yang maksimal. Disamping itu variabel tenaga kerja juga cukup berperan dalam peningkatan produktifitas sawit di Kecamatan Seluma Barat. Dari hasil penelitian dapat kita ketahui bahwa tenaga kerja yang digunakan masih kurang produktif artinya tenaga kerja yang dipakai oleh petani dalam proses produksi sawit belum dimanfaatkan dengan sebaik-baiknya.

\section{Pengujian Hipotesis Secara Parsial}

Pengujian koefisien secara parsial (t-test), digunakan untuk menguji adanya pengaruh masingmasing variabel independen terhadap variabel dependen yaitu produksi sawit. Untuk menguji masing-masing variabel, digunakan uji-t dengan tingkat kepercayaan $95 \%$ adalah sebagai berikut:

a. Untuk pengujian terhadap adanya pengaruh luas lahan $\left(\mathrm{X}_{1}\right)$ terhadap jumlah produksi sawit $(\mathrm{Y})$ di Kecamatan Seluma Barat Kabupaten Seluma maka dilakukan uji-t dengan level signifikan $\alpha=$ 0,05. Dari hasil perhitungan diketahui nilai $\mathrm{t}_{\text {tabel }}=1,960$ dan hasil estimasi untuk $\mathrm{t}_{\text {hitung }}$ luas lahan $\left(\mathrm{X}_{1}\right)=4,901$, karena $t_{\text {hitung }}>\mathrm{t}_{\text {tabel }}$, atau 4,901 $>1,960$ maka dapat disimpulkan bahwa luas lahan tersebut berpengaruh sangat nyata $($ sig. $=0,000)$ terhadap produksi sawit di Kecamatan Seluma Barat Kabupaten Seluma.

b. Untuk menguji adanya pengaruh penggunaan tenaga kerja $\left(\mathrm{X}_{2}\right)$ terhadap jumlah produksi sawit (Y) di Kecamatan Seluma Barat maka dilakukan uji-t dengan level signifikan $\alpha=0,05$. Dari hasil perhitungan diketahui nilai $t_{\text {tabel }}=1,960$ dan hasil estimasi untuk $t_{\text {-hitung }}$ tenaga kerja $\left(X_{2}\right)=1,534$, karena $\mathrm{t}_{\text {hitung }}<\mathrm{t}_{\text {tabel }}$ atau 1,534 $<1,960$, maka dapat disimpulkan bawa tenaga kerja yang digunakan tidak berpengaruh nyata (sig. 0,072) terhadap produksi sawit di Kecamatan Seluma Barat Kabupaten Seluma.

c. Untuk pengujian adanya pengaruh modal $\left(\mathrm{X}_{3}\right)$ terhadap jumlah produksi $(\mathrm{Y})$ di Kecamatan Seluma Barat Kabupaten Seluma maka dilakukan uji-t dengan level signifikan $\alpha=0,05$. Dari hasil perhitungan diketahui nilai $t_{\text {tabel }}=1,960$ dan hasil estimasi untuk $t_{\text {hitung }}$ pupuk $\left(X_{3}\right)=2,926$, karena $t_{\text {hitung }}<\mathrm{t}_{\text {tabel }}$ atau 2,926>1,960, maka dapat disimpulkan bahwa penambahan modal tersebut berpengaruh nyata (sig. 0,004) terhadap produksi sawit di Kecamatan Seluma Barat Kabupaten Seluma.

\section{Pengujian Hipotesis Secara Simultan}

Pengujian hipotesis secara simultan, digunakan untuk mengetahui apakah variabel independen (luas lahan, tenaga kerja, dan modal) memiliki pengaruh secara bersama-sama terhadap variabel dependen, maka dilakukan uji $\mathrm{F}$ pada tingkat kepercayaan $95 \%$. 
Hasil perhitungan dengan model regresi linear berganda, diperoleh nilai F-hitung 86,513 dan nilai F-tabel 2,840, karena F-hitung > F-tabel maka dapat disimpulkan bahwa variabel independen (luas tanah, tenaga kerja, dan modal) berpengaruh nyata terhadap variabel dependen (produksi sawit).

Dari hasil penelitian diperoleh nilai koefisien korelaasi (R) dari 42 responden yaitu sebesar 0,835 yang artinya secara keseluruhan variabel dipengaruhi dan mempunyai hubungan sangat erat dan positif terhadap variabel terpengaruh. Perhitungan secara kuantitatif hasil penelitian diperoleh nilai koefisien determinasinya $\left(\mathrm{R}^{2}\right)$ adalah 0,697 artinya produksi sawit bisa dijelaskan oleh luas lahan, tenaga kerja, dan modal sebesar 69,7\% sedangkan 30,3\% disebabkan oleh faktor lain yang tidak dimasukkan dalam fungsi produksi tersebut diatas.

\section{KESIMPULAN}

Berdasarkan hasil pembahasan bab sebelumnya tentang bagaimana pengaruh faktor produksi yaitu: luas lahan, tenaga kerja, dan modal terhadap jumlah produksi kelapa sawit di Kabupaten Seluma Barat, maka dapat dirumuskan kesimpulan sebagai berikut:

1. Hasil penelitian dengan menggunakan rumus Cobb-Douglas ditemukan besarnya koefisien regresi luas lahan adalah sebesar 0,774 , tenaga kerja sebesar 0,348 , dan modal sebesar 0,430 , ketiga variabel tersebut berpengaruh positif terhadap jumlah produksi sawit di Kabupaten Seluma. Hal ini mengandung makna bahwa setiap tambahan satu satuan masing-masing variabel yang diteliti akan menyebabkan tambahan satu satuan jumlah produksi kelapa sawit di Kabupaten Seluma selama 2011-2015.

2. Hasil perhitungan secara induvidu (persial) diperoleh dengan pengujian hipotesis uji-t dengan tingkat signifikan $\alpha=0.05$ ditemukan bahwa besarnya variabel $t_{\text {hitung }}$ masing-masing variabel yaitu : (1) luas lahan $\left(X_{1}\right)=4,901$, sehingga 4,901 >1,960 atau $t_{\text {hitung }}>t_{\text {tabel }}$; (2) variabel tenaga kerja diperoleh $t_{\text {hitung }}\left(X_{2}\right)=1,534$, sehingga 1,534 $<1,960$ atau $t_{\text {hitung }}<t_{\text {tabel }} ;$; (3) modal diperoleh $t_{\text {hitung }}\left(X_{3}\right)=2,926$, sehingga 2,926 $>1,960$ atau $t_{\text {hitung }}>t_{\text {tabel }}$. Berdasarkan hasil uji-t tersebut dapat disimpulkan bahwa secara uji parsial variabel luas lahan $\left(\mathrm{X}_{1}\right)$ dan modal $\left(\mathrm{X}_{3}\right)$ berpengaruh secara signifikan terhadap jumlah produksi, sedangkan variabel tenaga $\left(\mathrm{X}_{2}\right)$ tidak cukup bukti berpengaruh terhadap jumlah produksi kelapa sawit di Kabupaten Seluma.

3. Hasil perhitungan secara menyeluruh (simultan) diperoleh uji $\mathrm{F}$ sebesar F-hitung $=86,513$ dengan nilai F-tabel $=2,840$, sehingga F-hitung $>$ F-tabel maka dapat disimpulkan bahwa luas lahan, tenaga kerja, dan modal secara simultan berpengaruh terhadap jumlah produksi sawit di Kabupaten Seluma.

4. Tingkat produktivitas kelapa sawit di Kabupaten Seluma setiap tahunnya cenderung menurun, produktivitasnya tahun 2015 yaitu sebesar 3,13. Kondisi ini dapat terjadi karena semakin banyaknya pohon kelapa sawit yang sudah semakin tua sehingga produksinya cenderung terus menurun. Selain itu faktor curah hujan, jenis pupuk dan umur tanaman, interaksi topografi dan buah mentah merupakan faktor-faktor yang menentukan produktivitas tanaman kelapa sawit di Kabupaten Seluma.

\section{REFERENSI}

\section{Artikel :}

Buleten PDB Pertanian.(2015). Pusat Data dan Sistem Informasi Pertanian Sekjen Kementerian Pertanian. Volume 14 Nomor 1. Februari 2015.

\section{Buku :}

Ari, S.(2001). Teori Ekonomi Makro. Yogyakarta: BPFE.

Bambang, R.(1995).Pembelajaran Perusahaan.Yogyakarta: YPBGM. 
Agus, A.(2006).Manajemen Produksi, Pengendalian Produksi. Yogyakarta: BPFE.

Beattie \& Taylor.(2004). Ekonomi Produksi. Yogyakarta: Gajah Mada University Press.

Billas, R A. (2005).Microeconomic Theory. 2 ed. Singapore: McGraw-Hill.

Danang, S.(2003). Metodologi Penelitian Ekonomi, Alat Statistik\& AnalisisOutput Komputer.Yogyakarta: CAPS.

Desy, A.(2013). Kamus Lengkap Bahasa Indonesia Terbaru. Surabaya: Amelia.

Djarwanto, P S. (1998).Statistik Non Parametrik.Yogyakarta: BPFE.

Djoyodipuro.(1994).Pengantar Ekonomi Untuk Perencanaan. Jakarta: UI Pres.

Hermanto. (2004). Perekonomian Indonesia. Jakarta: Erlangga.

Husen, U.(2007).Metode Penelitian Untuk Skripsi dan Tesis Bisnis.Jakarta: PT Grafindo Rajawali Persada.

Irawan \& M. Suparmoko.(2002).Ekonomi Pembangunan. Yogyakarta: BPFE.

Mubyarto. (2006). Pengantar Ekonomi Pertanian. Jakarta: LP3ES.

Nicholson, W.(2005). Teori Ekonomi Mikro, Prinsip Dasar dan Perluasan. Jakarta: Binarupa Aksara.

Raharja, Pratama dan Manurung, 2000. Teori Ekonomi Mikro. LPFEUI, Jakarta.

Pratama, R \& Mandala, M.(2006). Teori Ekonomi Mikro, SuatuPengantar. Jakarta: Fakultas Ekonomi UI.

Richard, L.(1994).Mikro Ekonomi Terjemah. Jakarta: PT Bima Aksara.

Sukirno, S.(2006).Pengantar Ekonomi Mikro.Jakarta: PT Rajawali Grafindo Persada.

Sutrisno, H.(2009). Metode Research. Yogyakarta: Andi Offset.

Winardi. (2006). Pengantar Ekonomi Mikro. Suatu Pengantar dan Aplikasi. Jakarta: PT. Bima Aksara. 